\title{
Factors Shaping the Uptake of ICT in Science Classrooms. A Study of a Large- Scale Introduction of Interactive Whiteboards and Computers
}

\author{
Carme Grimalt-Álvaro ${ }^{\mathrm{a}}$, Jaume Ametller ${ }^{\mathrm{b}}$, Roser Pintó ${ }^{\mathrm{a}}$ \\ Corresponding author: Carme Grimalt Álvaro (Carme.Grimalt@uab.cat)

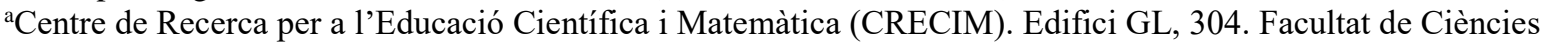 \\ de l'Educació. Universitat Autònoma de Barcelona. Bellaterra (Barcelona). 08193 Spain.

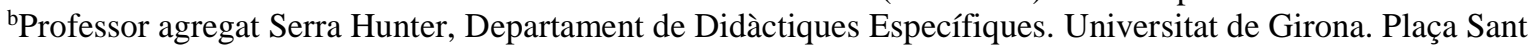 \\ Domènec, 9. Girona. 17004 Spain.
}

Keywords: secondary school, teachers, science, IWB, professional development, one-to-one International Journal of Innovation in Science and Mathematics Education, 27(1), 18-36, 2019

\begin{abstract}
This paper characterizes how science teachers use technology in secondary school lessons, with a special focus on Interactive Whiteboards (IWBs), laptops and Digital Textbooks (DTs). This study also analyses how previous professional development or training may influence the way in which teachers use technology in their subsequent practice, as well as some possible relations with their perceptions. A total of 94 teachers from 69 secondary schools in Catalonia (Spain) were surveyed. Responses were collected and analysed combining quantitative and qualitative methods. Participants' answers reveal the predominance of the use of IWBs and teachers' computers, with scarce variety of uses, mostly aimed at supporting teacher-centred practices. Students' participation in the use of these devices was low, calling into question the possible educational changes in science education. Although most teachers' training in the use of technology seems to have caused little impact on their subsequent practices, some less frequent training approaches, such as training based on real examples, seems more effective in terms of changing teachers' utilization of technology.
\end{abstract}

\section{Introduction}

The affordances of ICT tools are often referred to as enablers of educational change. However, research in this area shows that this connection is not unproblematic: studies on teachers' use of ICT have shown that, even when recognizing some possible benefits of using ICT in their lessons, they are unlikely to develop their understanding of how technology can improve the teaching and learning process (Aflalo, Zana, \& Huri, 2017; European Commission, 2013; Hammond, Reynolds, \& Ingram, 2011). Instead, the majority of teachers in those studies used ICT to design general activities pursuing only motivational and work-enhancing purposes.

From the perspective of science education, ICT offers a much wider range of benefits for improving teaching and learning: they can easily display abstract scientific ideas through images, graphs, animations, simulations, etc.; represent natural events that occur very fast/slowly or on a very big/small scale; summarise experimental results or ideas to identify patterns or draw conclusions. All these affordances can help students to better express their previous ideas about natural phenomena, to design experiments, establishing connections between scientific concepts or drawing conclusions about certain experimental results, among others (Grimalt-Álvaro, López Simó, \& Couso Lagarón, 2018; Hennessy \& London, 2013; 
Murcia, 2014), with ICT playing an important role in improving the quality of science education.

Thus, considering the gap between the multiple benefits of ICT for science education and its real use in class, it is necessary to understand how teachers' pedagogies can be changed to make the most of these tools.

\section{Factors affecting the use of ICT}

Many elements that are involved in or that can hinder the process of adopting technology in science classes have been identified in the literature. Some of them are obviously related to teachers having to contend with "technical" issues due to missing or inadequately provided equipment, and the lack of time or support available to implement the technology in teachers' environments (Baydas \& Goktas, 2016; Gutiérrez-Santiuste, Gallego-Arrufat, \& Simone, 2016). However, even when teachers are not confronted with technical difficulties, the use of ICT in the classroom does not necessarily lead to a shift in teaching methodology (Crook, Sharma, \& Wilson, 2014; Hennessy \& London, 2013; Pedró, 2011). This means that the introduction of these tools and their easy access does not in itself involve the development of any particular methods for teaching and learning: teaching with technology can either be learner-directed or teacher-directed, either focused on the individual or on collaboration, theoretical or inquiry-based (Crook \& Sharma, 2013; Hennessy \& London, 2013). In other words, research shows that the uses of ICT tools in classes, particularly in science lessons, are at the service of the teachers' pedagogical purposes. In view of this, teachers need to be actively involved in changing their own methodological paradigm to make the most of ICT.

Traditionally, research has classified all factors obstructing teachers' use of ICT either as barriers extrinsic to the teacher (ones related to the school as institution: logistics, lack of time or appropriate training, the school's ICT policy, etc.) or intrinsic barriers (associated with teachers' beliefs, their perspectives about the role of technology, their personal competence when using ICT, and their own capacities with these tools) (de Koster, Kuiper, \& Volman, 2012; Mama \& Hennessy, 2013; Prestridge, 2012). As it would be difficult to assess how the action of all these factors influence science teachers' ICT practices, in this paper we focus on the impact of professional development or training and teachers' beliefs. From our perspective, professional development can act as a barrier hindering the introduction of ICT and also plays a key role in shaping and changing teachers' practices and beliefs.

\section{Professional development of science teachers with ICT}

Research informs us that there is a relationship between teachers' digital competence and their use of ICT in the classroom (European Commission, 2013). Consequently, it is reasonable to assume that professional development will be an important factor to understand science teachers' use of ICT. However, although there is much evidence that science teachers have not been sufficiently trained to make the most of ICT tools for improving science education (Sheffield, 2015), there is still little research on how different types of professional development focused on the use of technology can influence subsequent practices with these tools. Such information would be relevant to decide upon the training needs of science teachers with different profiles to enable them to make better use of ICT in their practice.

Based on the previous literature, we have summarised and classified in Table 1 the three main approaches of professional development on ICT documented in international surveys, such as the Survey of Schools (European Commission, 2013), or in international studies, such as the works of Hennessy and London (2013) or Mouza and Barrett-Greenly (2015). These three 
approaches (technical characteristics, general uses and affordances of ICT and real examples from other teachers) will be the ones considered in this paper. We are aware that other professional development approaches exist, such as the participation in communities of practice (Couso, 2009) or the Teacher noticing groups (Sherin, Jacobs, \& Philipp, 2011). However, since our purpose is to assess the influence of the main professional training received on a relevant sample of teachers, these minor approaches will not be considered for this article.

Apart from the training approach, regarding which several authors agree that effective training on ICT should be content-specific (Couso, 2009; Departament d'Ensenyament, 2018; Ertmer \& Ottenbreit-Leftwich, 2010; Hennessy \& London, 2013), other factors affecting the impact of professional development on teachers' practices have been described. In this sense, the length of the training received is also a significant factor in terms of changing teachers' practices with ICT: effective teacher training should be a long-term process in order to appropriately support teachers in their own process of technology integration at school (Couso, 2009; Faulder, 2011).

Table 1: Main training approaches documented in international surveys on professional development in ICT considered in the study, based on (European Commission, 2013; Hennessy \& London, 2013; Mouza \& Barrett-Greenly, 2015)

\begin{tabular}{|l|l|}
\hline Training approach & Description \\
\hline $\begin{array}{l}\text { Technical } \\
\text { characteristics }\end{array}$ & $\begin{array}{l}\text { Equipment-specific training: basic computer literacy, dealing with hardware and } \\
\text { software applications without necessarily being connected to teaching and learning. } \\
\text { For example, how to turn on an Interactive Whiteboard, how to create a local } \\
\text { network for sharing files, and so on. }\end{array}$ \\
\hline $\begin{array}{l}\text { General uses and } \\
\text { affordances of ICT }\end{array}$ & $\begin{array}{l}\text { Pedagogical courses on the use of ICT: basic computer literacy as the main focus, } \\
\text { but this time in relation with or in support of general teaching and learning activities } \\
\text { (non-specific for science). For example, how to use a virtual campus to provide } \\
\text { immediate feedback to students, how to design a flipped classroom, and so on. }\end{array}$ \\
\hline $\begin{array}{l}\text { Real examples from } \\
\text { science teachers }\end{array}$ & $\begin{array}{l}\text { Science-specific training on teaching and learning applications with ICT based on } \\
\text { real examples from science teachers. For example, sharing or exchanging science } \\
\text { activities using ICT with other teachers. }\end{array}$ \\
\hline
\end{tabular}

\section{Teachers' beliefs about the use of ICT}

Teachers' beliefs or perceptions refer to their attitudes about education - about their confidence in affecting students, about the nature of knowledge, about causes of teachers' or students' performance (Pajares, 1992), and about the role of ICT in education. Through beliefs, individuals position themselves in relation the world and take decisions (Ertmer, OttenbreitLeftwich, Sadik, Sendurur, \& Sendurur, 2012). Consequently, individuals' beliefs strongly affect their behaviour. In other words, beliefs exert a filtering effect on individuals' behaviour, structuring, projecting, and redefining their thoughts and the way they process information (Pajares, 1992). For this reason, researchers have widely argued that teachers' classroom practices with ICT are highly influenced by their beliefs: teachers select technology applications that align with their existing beliefs about what constitutes "good" education (Tondeur, van Braak, Ertmer, \& Ottenbreit-Leftwich, 2017).

According to the literature, teachers' beliefs about ICT can be classified into 4 dimensions: 
- Self-efficacy beliefs: teachers' beliefs about their capacities as ICT users, based on the construct defined by Bandura (1993). More than knowledge, teachers will not use ICT if they do not believe in their ICT-skills (Ertmer \& Ottenbreit-Leftwich, 2010).

- Beliefs about teaching and learning: General beliefs about the role of teachers and students in teaching and learning processes and their ideals about education (Ertmer \& Ottenbreit-Leftwich, 2010; Hu, 2006). Research provides wide evidence of the relationships between how technology is used and teachers' beliefs of what a "good" lesson should be like (Tondeur et al., 2017).

- Beliefs about the value of technology for teaching and learning: beliefs about how ICT can help teachers achieve their educational purposes, which are strongly related to teachers' knowledge about characteristics of ICT (Ertmer \& Ottenbreit-Leftwich, 2010; Glazewski, Ottenbreit-Leftwich, Ertmer, \& Newby, 2010).

- Beliefs about external factors: The use of ICT is also conditioned by teachers' beliefs about their cultural and social context, the management of the school, and so on (Ertmer \& Ottenbreit-Leftwich, 2010). Although these beliefs are not purely educational, they can play an important role in the integration of ICT in classes.

Although this classification can help to understand what motivates teachers to use ICT in a certain way, no concluding references in the literature can be found about specific science teachers' beliefs on ICT and, in particular, regarding ICT affordances for science teaching and learning, as described above. This knowledge would contribute to a better understanding of how these tools are used in science lessons.

\section{Context of study}

This research focuses on secondary schools in Catalonia (Spain) which participated in the EduCAT 2.0 programme. This programme combined a typical one-to-one programme (one computer per student) with the introduction of IWBs in all classrooms. The EduCAT 2.0 programme was first implemented in 2009, providing secondary school students and teachers with access to Interactive Whiteboards (IWB), laptops and digital textbooks (henceforth, oneto-one equipment). State-supported schools could join the programme on a voluntary basis. So far, the programme has been implemented in 600 , out of 1108 , secondary schools. Recently, some of these schools have started to replace laptops with tablets, broadening the range of potential uses of ICT that can be found in classrooms. This suggests that our research has looked at schools that have reached a phase of "mature technology" (Drayton, Falk, Stroud, Hobbs, \& Hammerman, 2010).

This simultaneous introduction of one-to-one tools and IWBs was pioneering within the international landscape of programmes introducing ICT in schools, and allowed us to study this unique educational context. Since then, we have observed that this simultaneous introduction of different ICTs is becoming more frequent around the world. In this sense, in order to avoid bias in our results due to the turbulence of the first stages of technology introduction, we have started our research two years after the implementation of the EduCAT programme (i.e., after an early stage of consolidation) (Rogers, 2003). This decision will also allow us to draw more informed conclusions regarding the appropriate design of teacher training. 


\section{Research questions}

The aim of this investigation is to assess the influence of the three main types of professional development received by teachers participating in the EduCat 2.0 programme, two years after the program started. To attain this objective, the investigation is structured around the following research questions:

- Q1 - How are one-to-one equipment and IWBs used specifically during science lessons by teachers?

- Q2 - Which synergies of use can be identified from the way the different ICT tools are used in science lessons?

- Q3 - What is the influence of professional training in the use of one-to-one equipment on teaching practices?

- Q4 - What beliefs do science teachers hold about the use of one-to-one equipment in their lessons during a mature phase of technology integration?

\section{Materials and methods}

To provide a broad perspective to answer the research questions, we have combined qualitative and quantitative analysis methods based on the use of a questionnaire as an instrument for data collection. The use of a questionnaire was motivated by the aim to reach a considerable number of science teachers to gather a broad perspective of uses, training and beliefs about ICT. The combination of quantitative and qualitative analyses allowed us to contextualise the questionnaire answers, providing additional information which is often missing from purely quantitative questionnaires, and enabling us to obtain a more reliable interpretation of the quantitative data.

\section{Questionnaire design}

A questionnaire was designed in order to answer the research questions. Thus, the structure of the questionnaire was divided into four parts to facilitate reader response, as Bradburn, Sudman and Wansink (2004) recommend. These parts, which are described in Table 2, are: Information about the school and teacher data; professional information and previous training; information about the use of ICT in the classroom; and science teachers' opinions about the use of ICT in their lessons. In order to facilitate the subsequent data analysis, all questions of the questionnaire were closed, except for the ones related to teachers' opinions about ICT (part 4). Questions about professional information and previous training were based on the training approaches described and documented in the literature (Table 1).

Since more reliable data is obtained when respondents are asked about usual behaviour in an exact time period rather than when asked in general (Bradburn et al., 2004), we decided to relate the questions about frequency of use of ICT (part 3, Table 2) to the respondents' last working week. We chose this time frame because it was short enough to be remembered at the time of answering the questionnaire, and long enough to include several opportunities for using ICT. Moreover, to better determine possible over- or under-reporting in the information gathered, a question in which teachers were required to express whether their behaviour during the previous week could be considered typical of their ICT use was added next to each question about ICT frequencies and uses. 
Table 2: Parts of the questionnaire used to answer the research questions

\begin{tabular}{|l|l|}
\hline Part & \multicolumn{1}{|c|}{ Aim } \\
\hline 1 & $\begin{array}{l}\text { Information about the school and teachers' data: name of the school, location and } \\
\text { teachers' gender were requested in order to track teachers' responses and perform a } \\
\text { demographical characterization of the sample. }\end{array}$ \\
\hline 2 & $\begin{array}{l}\text { Professional information and previous training: Overall teaching experience and } \\
\text { characterization of current teaching tasks, types and duration of professional } \\
\text { development for each of the EduCAT 2.0 programme tools and professional experience } \\
\text { using ICT in classrooms., Only four main types of training approaches were considered } \\
\text { in order to unify teachers' responses. }\end{array}$ \\
\hline 3 & $\begin{array}{l}\text { Information about the use of ICT in the classroom: Frequencies of use of ICT available } \\
\text { in school (hardware and software) and particularly about the use of IWBs, laptops and } \\
\text { digital textbooks. These questions were drawn from Becta Surveys about technology use } \\
\text { of in-service teachers (Becta, 2010), which have proven acceptable values of validity and } \\
\text { reliability. However, we adapted these questionnaires to focus on the use of one-to-one } \\
\text { equipment and the Catalan context. }\end{array}$ \\
\hline 4 & $\begin{array}{l}\text { Science teachers' opinion: Open questions to capture teachers' views on the affordances } \\
\text { and uses of ICT in classrooms. }\end{array}$ \\
\hline
\end{tabular}

The questionnaire was piloted with 4 science teachers, and the results were used to refine the questionnaire. In particular, participants in the pilot test highlighted the need to consider sponsored training by publishers, based on real examples. Thus, a fourth training approach, materials and examples designed by a publisher, was added to the three training approaches mentioned in Table 1 . Moreover, the pilot test helped us identify some misleading questions that were subsequently rephrased.

The survey was hosted on the research group's server. A link to the survey was e-mailed to the heads of science of all secondary schools taking part in the one-to-one project during the 201213 academic year. Science teachers responding to the survey were automatically provided with a username and password that allowed them to pause and resume the answering if necessary. Data from the teachers was saved on a database with protected limited access to research group members. Due to a lack of enough demographical information of the universe of potential respondents, we cannot test the representativeness of our sample and hence we must consider our respondents as constitutive of a convenience sample (Bradburn et al., 2004).

\section{Data analysis}

Data gathered in the survey was analysed using qualitative and quantitative methods as follows:

- Research questions 1, 2 and 3 were addressed through descriptive and inferential statistics using SPSS 19.0 software (SPSS Inc., Chicago, IL, USA) to analyse teachers' responses to parts $2 \& 3$ of the questionnaire (Table 2). Frequencies of use of different types of technology were calculated in percentages considering the total amount of lessons they taught during a given week. As gathered data was non-parametric, MannWhitney $U$ tests were used to reveal significant differences in teachers' use of one-toone equipment due to their participation in different types of professional development. 
- Research question 4 was addressed by content analysis techniques of responses to the $4^{\text {th }}$ part of the survey (Table 2) using ATLAS.ti 7 (ATLAS.ti Scientific Software Development $\mathrm{GmbH}$, Berlin). Teachers' opinions were classified into categories that were grounded in the data collected and underpinned by the findings in the literature. The proposed categories were subsequently modified and optimized to saturation.

Moreover, since there is very scarce information about changes produced by this programme in participant schools, we have used data from other international one-to-one projects to draw conclusions, such as the works of López and Pintó (2011) and Padrós Rodríguez (2011).

\section{Results and discussion}

\section{Sample description}

A total of 94 science teachers from 69 different schools answered the survey, 79 of whom completed the entire questionnaire. The sample amounts to $15.7 \%$ of overall Secondary Schools taking part in the one-to-one project. The average profile of the respondent was a woman $(65 \%)^{1}$, with a teaching experience of between 11 and 30 years $^{2}$, and a mean experience of 2 years using ICT in the classroom ${ }^{3}$, which coincided with the duration of the one-to-one project at that time.

A comparison between the demographical characteristics of the group of participants of the survey and samples from similar studies previously conducted at the same national level was performed in order to assess any possible bias of the responses. Some differences between the sample obtained and the population were found in terms of gender, years of experience and types of educational centres (Consell Superior d'Avaluació del Sistema Educatiu, 2010; Padrós Rodríguez, 2011). However, the census used for these comparisons includes all secondary schools (not only those taking part in the one-to-one programme) and all teachers, without specifying the subject taught. Thus, although the characteristics of this census might differ from that of our target universe (science teachers in schools taking part in the one-to-one programme), there is no further data available to allow us to assess the difference between these two groups. In the absence of other studies addressing these issues in a comparable sample, we cannot assess the predictive or concurrent validity of our data. Other national and international research has been used as a context for the discussion of our results.

Since we can consider our study to be the first of its kind in our school context, we have relied on the face and content validity of our data by: (a) mapping the elements of teachers' use of ICT addressed in our study to similar previous studies and (b) discussing our questionnaire with experts. The reliability of the data obtained with the questionnaire has been reinforced by cross-referencing between the responses of teachers and subsequent classroom observations and interviews (Jaillet, 2004) of a sample of teachers teaching in schools taking part in the oneto-one programme (Grimalt-Álvaro, 2016).

\footnotetext{
${ }^{1} \mathrm{x}=1.65, \mathrm{o}=.480, \mathrm{~N}=94$. Being $1=$ male, $2=$ female

${ }^{2} \mathrm{x}=4.79, \sigma=1.544, \mathrm{~N}=94$. Being $1=<1$ year, $2=1-3$ years, $3=4-10$ years, $4=11-20$ years, $5=21-30$ years, $6=31-40$ years, $7=>40$ years

${ }^{3} \mathrm{x}_{\mathrm{IWB}}=3.16, \sigma_{\mathrm{IWB}}=1.120, \mathrm{~N}=76 ; \mathrm{x}_{\mathrm{DT}}=3.11, \sigma_{\mathrm{DT}}=1.066, \mathrm{~N}=82 ; \mathrm{x}_{\mathrm{Laptop}}=3.25, \sigma_{\text {Laptop }}=1.067, \mathrm{~N}=75 ;$ being $1=$ never used these tools, $2=<1$ year of experience, $3=1-2$ years, $4=2-3$ years, $5=>3$ years
} 


\section{Question 1: Use of one-to-one equipment and IWBs during Science lessons by teachers}

\section{Use of the IWB}

When asking specifically about the uses of IWBs, teachers' answers showed a variety of situations that are displayed in Figure 1. Results show that this tool is mostly used to show digital textbooks ${ }^{4}$ or project slides ${ }^{5}$. Interactive features of IWBs, such as teachers' writing on the screen, are underused. At a second level, the IWB was used for searching information ${ }^{6}$, making annotations on the IWB to support teachers' explanations (Teachers' writing) ${ }^{7}$ and showing videos or dynamic information ${ }^{8}$ (see Appendix 1 for a more detailed description of the uses). Figure 1 also shows that the main uses of the IWB are intended to display information (such as digital textbook or slide presentation showing), and IWB uses intended to generate new information (teachers or students writing on the board) are less frequent in science lessons. Uses that imply the participation of students, such as students' writing on the board ${ }^{9}$ or students' interacting with the $I W B^{10}$, were less frequent.

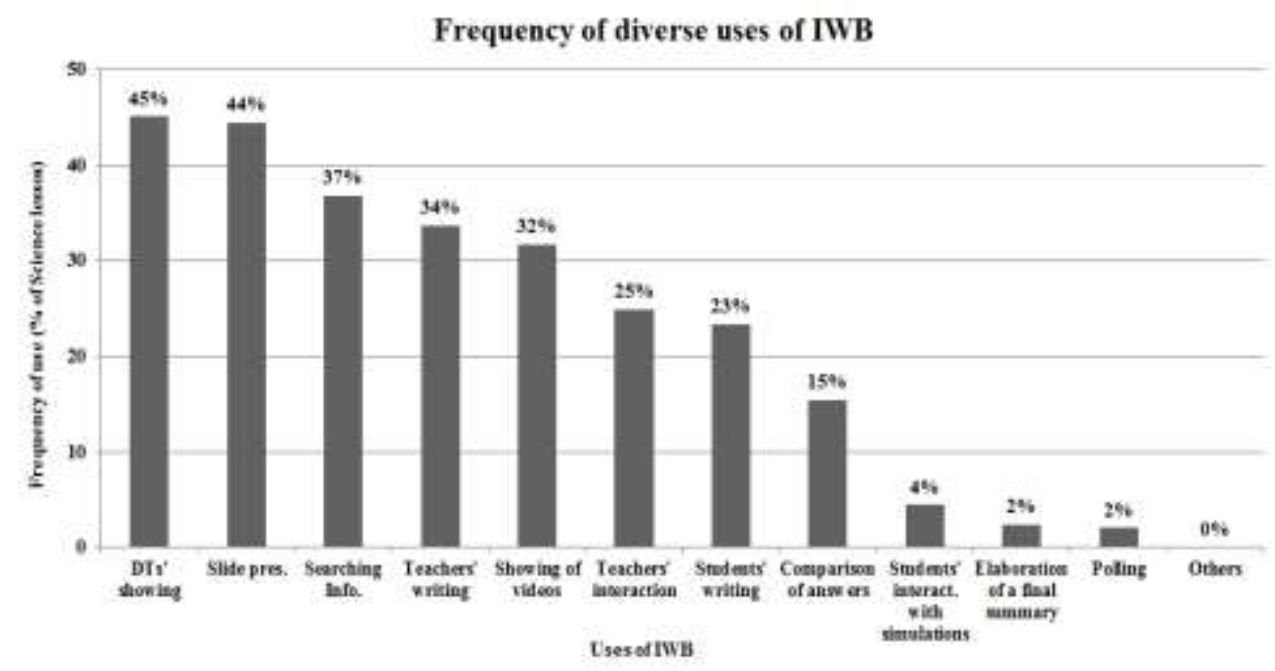

Figure 1: Frequencies of different uses of IWB by Science teachers, expressed in percentage of Science lessons where each of these ICTs were used. DT stands for Digital Textbooks

These results would suggest that, in a mature state of technology integration, the IWB would still be usually reduced to a common projector in the majority of science lessons. Moreover, most frequent uses of the IWB indicate a predominance of the role of the teacher in classroom development. Thus, it would seem that the use of IWBs in science lessons has not fostered student participation in the construction of scientific knowledge, as has also been reported by other studies (Hennessy \& London, 2013). In particular, it seems that teachers have not taken advantage of the specific affordances of the IWBs for teaching and learning science, as reported above (displaying scientific ideas, representing natural events that occur very fast/slowly, etc.), thereby lessening the potential impact of this tool for improving science education.

\footnotetext{
${ }^{4} \mathrm{x}_{\mathrm{DT} \text { _show }}=45.08, \sigma_{\mathrm{DT} \text { show }}=38, \mathrm{n}=55$

${ }^{5} \mathrm{X}_{\text {Slide_pres }}=44.42$, $\sigma$ Slide_pres $=35, \mathrm{n}=55$

${ }^{6} \mathrm{X}_{\text {Searching_info }}=36.76$, OVirtual_plat $=33, \mathrm{n}=55$

${ }^{7} \mathrm{x}_{\text {Teachers'_writing }}=33.65$, OTeachers'_writing $=39, \mathrm{n}=55$

$8 \mathrm{x}_{\text {Show video }}=31.74, \sigma_{\text {Show } v \text { video }}=24, \mathrm{n}=55$

${ }^{9} \mathrm{X}_{\text {Students_writ }}=23.29$, OStudents-writ $=35, \mathrm{n}=55$

${ }^{10} \mathrm{X}_{\text {Students_interact }}=4.41$, OStudents_interact $=15, \mathrm{n}=55$
} 
These results are similar to other general studies (non-discipline specific) reporting the use of IWBs in an early stage of technology integration, such as the works of Hammond et al. (2011) and Hennessy and London (2013). These similarities would suggest that the use of the IWB is not a particularity of the context or the subject, but a common situation in classrooms across different countries, and that the stage of technology integration (and the experience of using the tool) may have little influence on its use. Thus, it is necessary to assess the impact of factors such as teacher training, or beliefs about the use of ICT of science teachers, to better understand the situation described.

\section{Use of laptops}

Laptops were mainly employed in science lessons to support the use of digital textbooks (DTs consulting) $)^{11}$, as well as for the production of work through the use of office tools $^{12}$ (Figure 2). Other uses of laptops, like communication via Internet (mail, chats, social networks), use of interactive resources (like simulations or conceptual maps), or tools for group working appeared less frequently ${ }^{13}$.

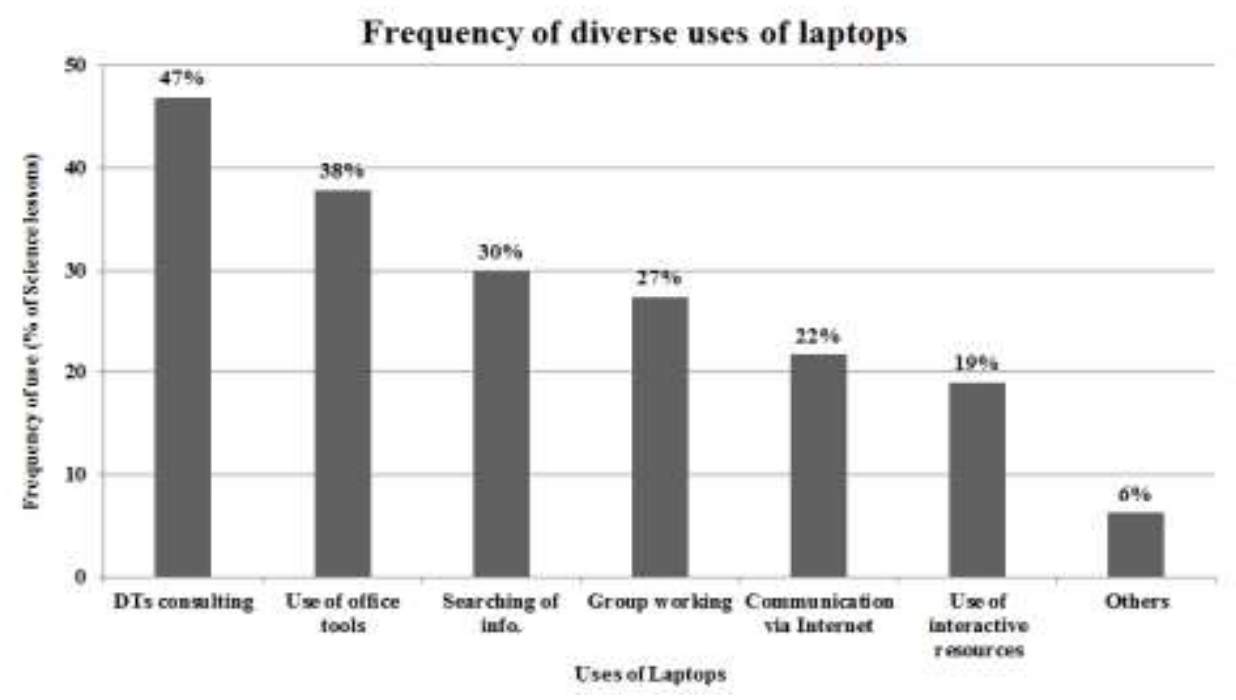

Figure 2: Frequencies of different uses of laptops in Science lessons, expressed in percentage of Science lessons in which laptops were used. DT stands for Digital Textbooks

Unlike the use of IWBs, results from the questionnaire indicate some link between the use of laptops and the promotion of students' autonomous work through the use of office tools. However, these results also show that the main uses of laptops do not take advantage of their specific affordances to promote scientific competences, since main uses are based on retrieving and managing information - that is, emulating textbooks and notebooks.

\section{Use of digital textbooks}

Digital Textbooks (DTs) were mainly used as a basic source of information for teaching new

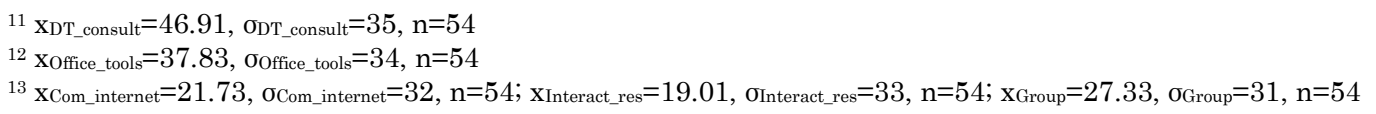


content $^{14}$ (Figure 3). Solving simple exercises ${ }^{15}$ and doing isolated searches ${ }^{16}$ were also significant. Comparatively, other uses like using simulations, watching videos, formative assessment or collaborative working activities are much less frequent ${ }^{17}$. These results are coherent with the main uses of IWBs and student laptops, as reported above, increasing the reliability of the data obtained.

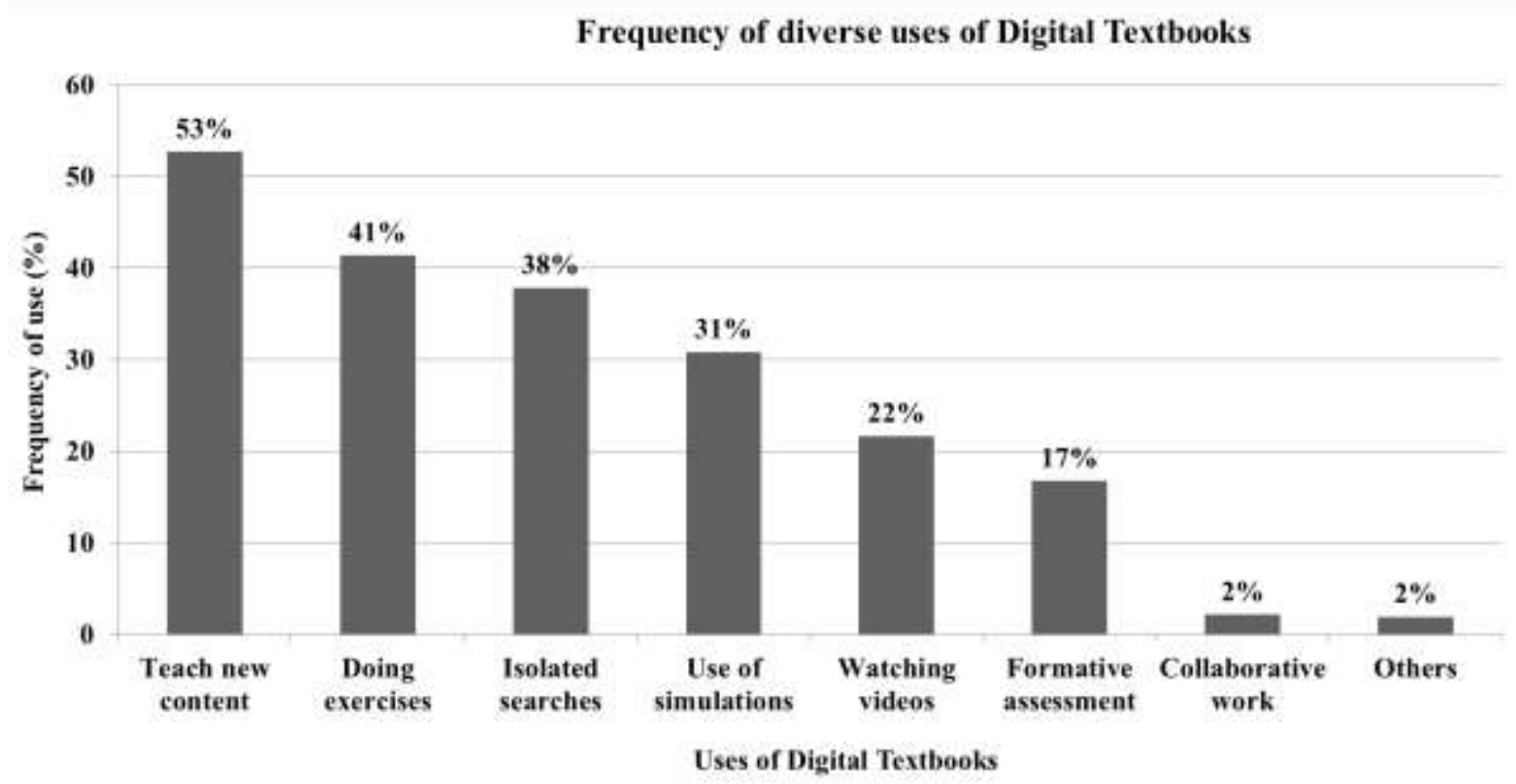

Figure 3: Frequencies of different uses of Digital Textbooks by Science teachers, expressed in percentage of Science lessons where each of these ICTs were used

\section{Question 2: Synergies between the uses of the one-to-one equipment and IWBs for science teaching in secondary schools}

Overall, compared to all types of hardware available in secondary school classes, desktop computers, IWBs and teachers' laptops were the most used tools in science lessons ${ }^{18}$, with students' laptops being used considerably less ${ }^{19}$. This situation shows that IWBs, digital textbooks and laptops have been successfully introduced in teaching and learning routines and, in a mature stage of introduction, they are still usually used. However, previous results prompt us to question if this introduction has also involved a shift in science education.

Previous results, as well as qualitative information gathered through the questionnaire, allow us to infer some synergies of use between the IWBs, laptops and digital textbooks. Two vignettes can be drawn to illustrate the synergies identified:

- Vignette 1: ICTs are used to support traditional lectures. In particular, the teacher uses the IWB to show information (either using the digital textbook or a slide presentation). Less frequently, the teacher searches for information on the Internet, writes and takes

\footnotetext{
${ }^{14} \mathrm{x}_{\text {Teach_new }}=52.63, \sigma_{\text {Teach_new }}=36, \mathrm{n}=52$

${ }^{15} \mathrm{x}_{\text {Exercises }}=41.35$, $\sigma_{\text {Exercises }}=34, \mathrm{n}=52$

${ }^{16} \mathrm{x}_{\text {Consult }}=37.81, \sigma_{\text {Consult }}=34, \mathrm{n}=52$

${ }^{17} \mathrm{x}_{\text {Simulations }}=30.82, \sigma_{\text {Simulation }}=31, \mathrm{n}=52 ; \mathrm{x}_{\text {Watch }}=21.64, \sigma_{\text {Watch }}=21, \mathrm{n}=52 ; \mathrm{x}_{\text {Formative_assessment }}=16.73$, $\sigma_{\text {Formative_assessment }}=29, \mathrm{n}=52$; $\mathrm{x}_{\text {Col_work }}=2.12, \sigma_{\text {Col_work }}=10, \mathrm{n}=52$

${ }^{18} \mathrm{x}_{\text {Desktop_computers }}=54.62, \sigma_{\text {Desktop_computers }}=43, \mathrm{n}=66 ; \mathrm{x}_{\mathrm{IWB}}=54.00, \sigma_{\mathrm{IWB}}=39, \mathrm{n}=67 ; \mathrm{x}_{\text {teachers'_laptops }}=53.96, \sigma_{\text {teachers'_laptops }}=44, \mathrm{n}=64$

${ }^{19} \mathrm{X}_{\text {Students'_laptop }}=37.21$, OStudents'_laptop $=41, \mathrm{n}=64$
} 
some notes, and displays videos. In these lectures, students occasionally use their laptops to look up information on their digital textbooks while the teacher is lecturing. Students may also use their laptops to take notes about the lecture, but much less frequently. Thus, the IWB, the DT and laptops are used simultaneously.

- Vignette 2: Students use their laptops to look up information on their digital textbooks, practice (do exercises, search for information on the Internet, use office tools, etc.) and work more autonomously either individually or in groups. We could expect that, in this situation, the lesson would be more student-centred than in Vignette 1. However, more research is needed to clarify the role of the IWB in this second vignette.

These two vignettes lead us to highlight the following synergies:

- The IWB and DT are used simultaneously to support teachers' lectures and, thus, emulate a traditional projector displaying information.

- The IWB, the DT and students' laptops are also used to support teachers' lectures, but the simultaneous use of these three tools is less frequent. In this situation, laptops emulate traditional textbooks.

- Students' laptops and DTs are also used to promote students' autonomous work. In this situation, DTs and laptops also emulate traditional textbooks and students' notebooks.

These combined uses also illustrate how the IWB is exclusively reserved for teachers' use, restricting the space of student participation. In contrast, laptops are mostly used by students and digital textbooks by both teachers and students. These results show similarities with the reported uses indicated in the literature on IWBs (Hennessy \& London, 2013). Thus, although more ICTs have been introduced in classrooms, teachers' educational purposes remain the same as before. Although we can question the benefits of the simultaneous introduction of IWBs, laptops, and digital textbooks for science education, this situation highlights the predominance of other factors that affect the use of these tools. In the following sub-sections, the influence of some of these factors is discussed.

\section{Question 3: Influence of professional training in the use of one-to-one equipment on teachers' IWB practices}

\section{Description of training received}

Teachers' training in digital textbooks and laptops was low (typically between 2-5 hours of training for DTs ${ }^{20}$ and laptops ${ }^{21}$, in contrast with 6-15 hours of training for IWBs ${ }^{22}$ ). The frequencies of teacher attendance at each training approach for the different ICT tools are reported in Figure 4. Results from the survey showed a low diversity of professional development activities: Teacher training based on general uses and affordances and technical characteristics were the most common teaching approach for IWBs and Laptops, though at different frequency rates (Figure 4). On the other hand, training based on materials and examples designed by a publisher and real examples from other teachers were less frequent for these tools.

\footnotetext{
${ }^{20} \mathrm{X}_{\mathrm{DT}}=2.52$; where $0=$ no training received, $1=<1 \mathrm{~h}$ of duration, $2=2-5 \mathrm{~h}, 3=6-15 \mathrm{~h}, 4=16-30 \mathrm{~h}$ and $5=>30 \mathrm{~h} ; \sigma_{\mathrm{DT}}=1 ; \mathrm{n}=77$

${ }^{21} \mathrm{x}_{\text {Laptop }}=2.66$; where $0=$ no training received, $1=<1 \mathrm{~h}$ of duration, $2=2-5 \mathrm{~h}, 3=6-15 \mathrm{~h}, 4=16-30 \mathrm{~h}$ and $5=>30 \mathrm{~h} ; \sigma_{\text {Laptop }}=1 ; \mathrm{n}=50$

${ }^{22} \mathrm{x}_{\mathrm{IWB}}=2.99$; where $0=$ no training received, $1=<1 \mathrm{~h}$ of duration, $2=2-5 \mathrm{~h}, 3=6-15 \mathrm{~h}, 4=16-30 \mathrm{~h}$ and $5=>30 \mathrm{~h} ; \sigma_{\mathrm{IWB}}=1 ; \mathrm{n}=79$
} 


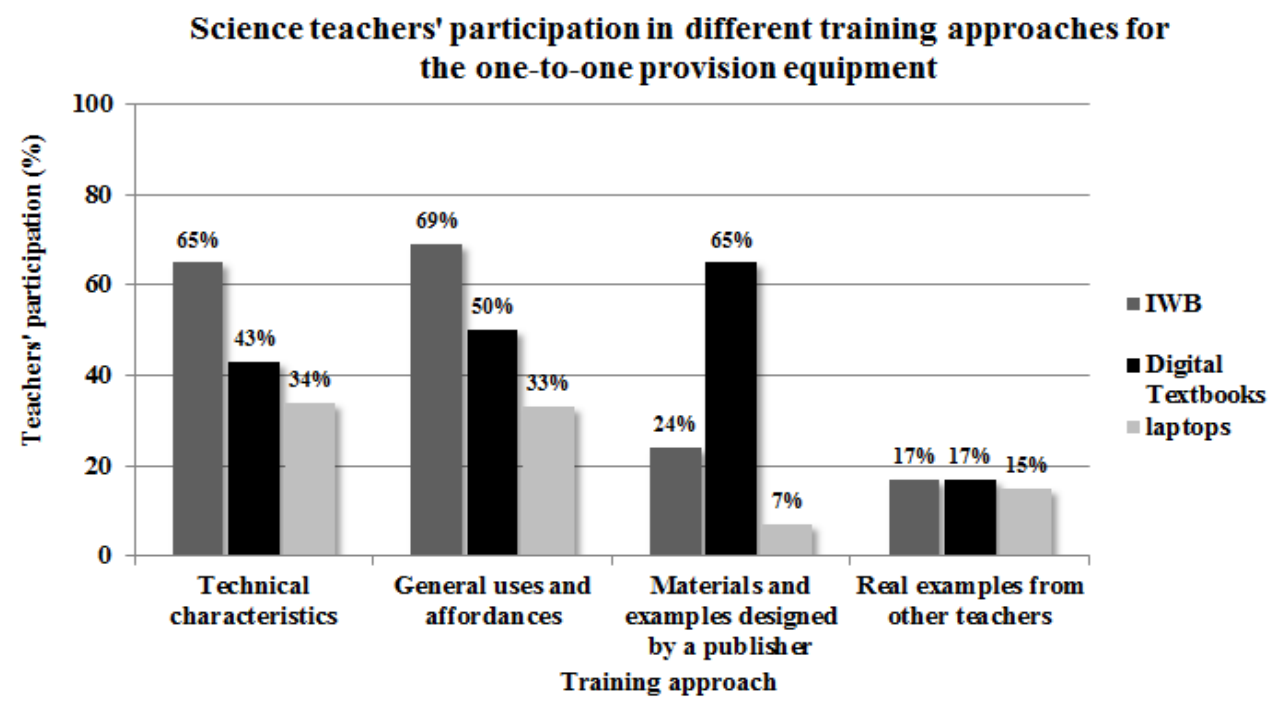

Figure 4: Participation of Science teachers in different training approaches for IWBs, digital textbooks and laptops. Percentages of teachers attending each training approach are calculated independently

The short length of the training received, especially for laptops and digital textbooks, might help to explain why teachers' uses of the ICT tools takes little advantage of their affordances for science education. As reported in the literature, effective training to promote the use of ICT must be a long-term activity in order to support teachers in their process of technology integration (Couso, 2009; Faulder, 2011), which can last between five to seven years (Ertmer, 2005). Moreover, the main type of training received throughout the introduction process (centred on technical characteristics and general uses) could have been another pitfall for promoting teachers' integration of specific affordances of these tools for science education. In addition, teacher training approaches for digital textbooks were mainly based on materials and examples designed by a publisher (Figure 4), revealing the significant role played by editorials when promoting the use of this tool. However, although the development of teachers' technical abilities is necessary in the initial stages of introducing a tool (Faulder, 2011), approaches that do not take into account teachers' needs and realities would not be effective when integrating ICT into classrooms in the mid- to long-term (Faulder, 2011). Thus, a low impact of participants' training on IWB uses is to be expected.

\section{Description of the influence of training received on teachers' use of the IWB}

Table 3 summarizes the results of the Mann-Whitney $U$ test to assess the possible impact of training on teachers' use of the IWB. The complete results of these tests can be found in Appendix 1. As laptops and digital textbooks are considerably less used in science lessons, we have focused our study on the IWB to avoid possible sample effect sizes. 
Table 3: Statistically significant differences between teachers' uses of the IWB (Figure 1) depending on the training approach received. Results are based on the MannWhitney $U$ test and are reported completely in Appendix 1. Positive effect: teachers who have participated in this training approach use the IWB more in this manner. Negative effect: teachers who have participated in this training approach use the IWB less in this manner.

\begin{tabular}{|c|c|c|c|c|}
\hline & \multicolumn{3}{|c|}{ TYPE OF PROFESSIONAL DEVELOPMENT } \\
\hline & & $\begin{array}{l}\text { Training based } \\
\text { on technical } \\
\text { characteristics }\end{array}$ & $\begin{array}{l}\text { Materials and } \\
\text { examples designed } \\
\text { by a commercial } \\
\text { publisher }\end{array}$ & $\begin{array}{l}\text { Real examples } \\
\text { from other } \\
\text { teachers }\end{array}$ \\
\hline \multirow{2}{*}{ 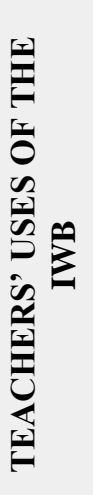 } & $\begin{array}{l}\text { Teachers' interactions } \\
\text { with the IWB (other } \\
\text { types of interaction } \\
\text { different from } \\
\text { writing, such as drag } \\
\& \text { drop or scroll } \\
\text { down) }\end{array}$ & --- & $\begin{array}{l}\mathrm{x}_{\mathrm{no}}=24.64, \\
\mathrm{x}_{\mathrm{yes}}=35.50, \\
\mathrm{U}=450.500, \mathrm{r}=.011) \\
\text { (positive effect) }\end{array}$ & $\begin{array}{l}\mathrm{X}_{\mathrm{no}}=23.56, \mathrm{x}_{\mathrm{yes}}=35.82, \\
\mathrm{U}=506.500, \mathrm{r}=, 003) \\
\text { (positive effect) }\end{array}$ \\
\hline & Realization of polls & $\begin{array}{l}\mathrm{X}_{\mathrm{no}}=30.44, \\
\mathrm{x}_{\mathrm{yes}}=27.00, \\
\mathrm{U}=273.000, \mathrm{r}=-.026) \\
\text { (negative effect) }\end{array}$ & $\begin{array}{l}\mathrm{X}_{\mathrm{no}}=27.00, \\
\mathrm{x}_{\mathrm{yes}}=30.24, \\
\mathrm{U}=361.000, \mathrm{r}=.033) \\
\text { (positive effect) }\end{array}$ & --- \\
\hline
\end{tabular}

At first glance, Table 3 reveals little impact of the different training approaches on the uses of IWBs (uses of IWBs are the same as the ones displayed in Figure 1). Only training based on materials and examples from a commercial publisher and real examples from other teachers have caused some statistically significant impact on teachers' uses of IWBs. In other words, teachers who participated in training based on materials and examples from a commercial publisher use the IWB more for interacting with it and for polling than teachers who did not participate in this training (positive effect); teachers who participated in training based on real examples from other teachers use the IWB more for interacting with it than teachers who did not participate in this training.

On the other hand, teacher training based on technical characteristics seems to have caused a negative effect on polling, with teachers who have participated in this training using the IWB for doing polls less (Table 3) than teachers who have not participated. It is worth highlighting the absence of any statistically significant differences in science teachers' uses of IWB due to general uses and affordances, which is the second most common type of training approach (Figure 4).

Research findings suggests that with appropriate professional development, teachers can acquire the knowledge, skills and resources to make the most of the affordances of this tool for improving teaching and learning processes (Hennessy \& London, 2013). However, our results reveal little impact of the training received on teachers' practices, calling into question not only the effectiveness of the main training approaches, but also the economic investment of the government. Moreover, the low impact of the main training approaches could explain the obstacles faced by science teachers when transferring general teaching knowledge and ICT practices to specific scientific teaching knowledge with technology. 
Effective training approaches (being the ones that have caused some positive impact on science teachers' performance with IWBs) are concrete (subject-specific) and based on teachers ' needs (based on real classroom examples). Thus, these training approaches are expected to generate greater impact on teachers' IWB practices when longer and more refined professional development courses are provided.

\section{Question 4: Science teachers' beliefs about the use of one-to-one equipment in their lessons}

Science teachers' opinions about the affordances of technology for science teaching purposes were also gathered in order to answer the last research question. The categorization of the responses into 9 categories was based on results from previous studies (Padrós Rodríguez, 2011) and the results obtained. The data collected is displayed in Table 4.

Table 4: Categorization of Science teachers' beliefs about the use of ICT in Science lessons. Frequencies are expressed in \% of total Science teachers' opinions obtained.

\begin{tabular}{|c|c|}
\hline Category description and examples & $\begin{array}{l}\text { Frequency } \\
\text { (\% of total) }\end{array}$ \\
\hline $\begin{array}{l}\text { ICT_P4 - Positive beliefs about ICT affordances to address teachers' } \\
\text { needs (e.g. ease of classroom management and communication) } \\
\text { "The use of technology makes lessons more dynamic." }\end{array}$ & 26 \\
\hline $\begin{array}{l}\text { ICT_P3 - Positive beliefs about characteristics of ICT for students' } \\
\text { learning of science: Inquiry, modelling, contextualization and access to } \\
\text { abstract concepts } \\
\quad \text { “(..) [I value] the possibility of modelling and simulating situations” }\end{array}$ & 15 \\
\hline $\begin{array}{l}\text { ICT_N4 - Negative beliefs about addressing teachers' needs: planning, } \\
\text { classroom management, quality of material and training received. } \\
\text { "Teacher training should be improved in particular. I still do not } \\
\text { know how to use all the available resources" }\end{array}$ & 15 \\
\hline $\begin{array}{l}\text { ICT_N5 - Negative beliefs about one-to-one program management } \\
\text { "The information that schools receive could be improved. At this } \\
\text { moment in time, we still don't know if the [one-to-one] project will } \\
\text { continue." }\end{array}$ & 15 \\
\hline $\begin{array}{l}\text { ICT_P1 - Positive beliefs about students' attitudes and motivation } \\
\text { "It is a more motivating environment for students." }\end{array}$ & 12 \\
\hline $\begin{array}{l}\text { ICT_P2 - Positive comments about the characteristics of ICT for students' } \\
\text { learning in general: work enhancement and interactivity } \\
\text { "Interactivity, the possibility to work at different paces and } \\
\text { collaboratively." }\end{array}$ & 12 \\
\hline $\begin{array}{l}\text { ICT_N1 - Negative comments about students' attitudes and attention } \\
\text { using ICT } \\
\quad \text { "Students are easily distracted when browsing the web." }\end{array}$ & 4 \\
\hline $\begin{array}{l}\text { ICT_O - Other teachers' beliefs (positive or negative) } \\
\text { "I personally agree with the initiative of introducing ICT in classrooms. } \\
\text { "We are abusing these tools when promoting students' learning” }\end{array}$ & 2 \\
\hline
\end{tabular}


The analysis of teachers' opinions shows that science teachers mostly hold positive views about the use of ICT in relation to the frequency of negative beliefs. Particularly, science teachers value technology for its affordances to address teachers' needs (ICT_P4, Table 4) and, with a lower percentage, for its affordances to promote students' scientific competences (ICT_P3). On the contrary, science teachers' opinions also show discomfort, mainly due to a lack of logistical and economical support (ICT_N5), inadequate training received, poor quality of available materials and difficulties when planning and managing the classroom (ICT_N4).

In comparison, results from science teachers' opinions show a positive evolution of perceptions about the use of ICT, compared to previous ones reported in the research by López \& Pintó (2011) and Padrós Rodríguez (2011), conducted both at national level, as well as with a small sample of teachers. This situation could be due to a progressive consolidation and normalization of the use of technology, as some authors suggest (Pedró, 2011; Rogers, 2003). However, the appearance of complaints about the lack of logistical, financial and teaching support remains significant in terms of response rates, which still show the presence of external barriers hindering technology integration.

The predominance of teachers valuing ICT's affordances to address teachers ' needs (ICT_P4, Table 4) and the use of ICT mainly with teacher-centred methodologies (Figure 1, Figure 2, and Figure 3) suggests the existence of relations between teachers' opinions or beliefs and the use of technology, and the consideration of these beliefs as a relevant factor to explain subsequent uses of technology, also reported by other authors (Mama \& Hennessy, 2013; Prestridge, 2012). Although these relations will be explored further in subsequent papers, these results suggest that teacher training should also contemplate and work with participants' beliefs in order to promote the integration of ICT in teachers' practices. Moreover, teachers' opinions reveal strong negative beliefs about the utility of the training received to help them use ICT (ICT_N4), confirming the need to revise the training approaches most frequently offered to teachers to maximise the benefits of the use of ICT for teaching and learning science.

\section{Conclusions of the research}

\section{Q1 - Most frequent uses of ICT are for supporting science teachers' practices in teacher-centred settings}

In general, the use of technology in science lessons is significant, with the IWB being shown to play a dominant role in science lessons. This tool, together with laptops and digital textbooks, is mostly used for presenting information. Teachers mainly make use of the available ICT through methodologies that are highly targeted at them at the expense of more student-centred and collaborative procedures. This also suggests that ICT is being used to reproduce or enrich existing teaching practices, supporting an established and conventional style of teaching, as has been found by other authors (Crook, Sharma, Wilson, \& Muller, 2013; Hammond et al., 2011; Prestridge, 2012). However, it would seem that these main uses are lessening the potential benefits of technology in student learning.

The similarities between these uses and the results of previous studies in the early stages of technology integration processes indicate that experiences using ICT may have little effect on changing teachers' practices and that other factors, such as training and teachers' beliefs, need to be considered. 


\section{Q2 - Teachers use digital textbooks to support their lectures on the IWB. Students use textbooks with their laptops to retrieve information and practice}

Synergies of use can be derived from the analysis of the frequencies of use of the different tools. These synergies depict combined uses of IWBs and digital textbooks to present information to students supporting teachers' lectures. Less frequently, according to the frequencies reported, students use their laptops to look up information on the digital textbook while the teacher is using the IWB for lecturing. Students' laptops and digital textbooks are also used to foster students' autonomous work.

Combined uses of the one-to-one provision illustrate how the IWB is exclusively reserved for teachers' use and how the public space for student participation is being restricted. In contrast, laptops are mostly used in combination with digital textbooks to foster students' autonomous work. The simultaneous introduction of ICTs may have contributed to reinforcing the wrong idea that there is technology exclusively for teachers' uses and technology exclusively for students' uses.

\section{Q3 - Main training received has caused little impact on teachers' practices with technology}

During all integration processes, science teachers' training in the use of technology has been mainly focussed on general uses and affordances and the technical characteristics of the IWB. However, there are no differences between the uses of IWB of teachers who participated in these training programmes and those who do not, revealing its inefficacy in terms of exploiting ICT for science education.

On the contrary, although training based on concrete examples (either from a publisher or from other teachers) has been less frequent, it has caused significant impact on teachers' practices with the IWB. From this perspective, training based on real examples takes on particular importance because it is content-specific and designed to address real teachers' needs. In other words, science teachers will be better able to integrate IWBs in their practice (will be more professionally developed) if they can see how this tool can address their needs in their everyday contexts.

\section{Q4 - Teachers' beliefs about the use of one-to-one equipment are consistent with their practices}

The affordances of ICT to address teachers' needs are what teachers most valued of technology after several years using it in their lessons. On the contrary, teachers' beliefs about the affordances of ICT for students' learning of science are much less frequent. These beliefs are fully consistent with the main uses of ICT, mainly devoted to support teachers' practices. Thus, effective training programmes should also consider and try to target teachers' beliefs in order to increase their effectiveness in changing the impact on teachers' technology-based practices.

\section{Disclosure statement}

No potential conflict of interest was reported by the authors.

\section{Acknowledgements}

This research has been financed by the EDU2015-66643-C2-1-P project of the Ministry of economy and competitiveness of Spain and has been carried out within the consolidated research group ACELEC (2017SGR1399). 


\section{Referencies}

Aflalo, E., Zana, L., \& Huri, T. (2017). The interactive whiteboard in primary school science and interaction. Interactive Learning Environments, O(0), 1-14. http://doi.org/10.1080/10494820.2017.1367695

Bandura, A. (1993). Perceived Self-Efficacy in Cognitive Development and Functioning. Educational Psychologist, 28(2), 117-148.

Baydas, O., \& Goktas, Y. (2016). Influential factors on preservice teachers' intentions to use ICT in future lessons. Computers in Human Behavior, 56, 170-178. http://doi.org/10.1016/j.chb.2015.11.030

Bradburn, N., Sudman, S., \& Wansink, B. (2004). Asking Questions. The definitive guide to questionnaire design. (First Edit). San Francisco: Jossey - Bass.

Consell Superior d'Avaluació del Sistema Educatiu. (2010). El projecte EduCAT 1x1. Una aproximació en la perspectiva de les directores i directors de centres participants (curs 2009 - 2010).

Couso, D. (2009). Science Teachers' Professional Development in Contexts of Educational Innovation. Analysis of three initiatives. From $\mathrm{PhD}$ dissertation.

Crook, S. J., \& Sharma, M. D. (2013). Bloom-ing heck! The activities of Australian science teachers and students two years into a 1:1 laptop program across 14 high schools. International Journal of Innovation in Science and Mathematics Education, 21(1), 54-69.

Crook, S. J., Sharma, M. D., \& Wilson, R. (2014). An Evaluation of the Impact of 1:1 Laptops on Student Attainment in Senior High School Sciences. Dx.Doi.Org, 37(2), 272-293. http://doi.org/10.1080/09500693.2014.982229

Crook, S. J., Sharma, M. D., Wilson, R., \& Muller, D. A. (2013). Seeing eye-to-eye on ICT: Science student and teacher perceptions of laptop use across 14 Australian schools. Australasian Journal of Educational Technology, 29(1), 82-95.

de Koster, S., Kuiper, E., \& Volman, M. (2012). Concept-guided development of ICT use in 'traditional' and 'innovative' primary schools: What types of ICT use do schools develop? Journal of Computer Assisted Learning, 28(5), 454-464. http://doi.org/10.1111/j.1365-2729.2011.00452.x

Departament d'Ensenyament. (2018). Competència digital docent del professorat de Catalunya.

Drayton, B., Falk, J. K., Stroud, R., Hobbs, K., \& Hammerman, J. (2010). After installation: Ubiquitous computing and high school science in three experienced, high-technology schools. The Journal of Technology, Learning and Assesment, 9(3).

Ertmer, P. A. (2005). Teacher pedagogical beliefs: The final frontier in our quest for technology integration? Educational Technology Research and Development, 53(4), 25-39. http://doi.org/10.1007/BF02504683

Ertmer, P. A., \& Ottenbreit-Leftwich, A. T. (2010). Teacher technology change: How knowledge, confidence, beliefs, and culture intersect. Journal of Research on Technology in Education, 42(3), 255-284.

Ertmer, P. A., Ottenbreit-Leftwich, A. T., Sadik, O., Sendurur, E., \& Sendurur, P. (2012). Teacher beliefs and technology integration practices: A critical relationship. Computers \& Education, 59(2), 423-435. http://doi.org/10.1016/j.compedu.2012.02.001

European Commission. (2013). Survey of Schools: ICT in Education. Belgium. Retrieved from https://ec.europa.eu/digital-agenda/en/pillar-6-enhancing-digital-literacy-skills-and-inclusion

Faulder, T. R. (2011). Technology integration: A research-based professional development program. M.Ed Thesis, Cedarville University.

Glazewski, K. D., Ottenbreit-Leftwich, A. T., Ertmer, P. A., \& Newby, T. J. (2010). Teacher value beliefs associated with using technology: Addressing professional and student needs. Computers \& Education, 55(3), 1321-1335. http://doi.org/10.1016/j.compedu.2010.06.002

Grimalt-Álvaro, C. (2016). La tecnologia a les classes de ciències de secundària: anàlisi dels processos de canvi en el professorat. Universitat Autònoma de Barcelona. Retrieved from http://www.tdx.cat/handle/10803/367210

Grimalt-Álvaro, C., López Simó, V., \& Couso Lagarón, D. (2018). Analysis of the role of Interactive Whiteboard (IWB) for promoting students' scientific practices in secondary labwork. In O. E. Finlayson, E. McLoughlin, S. Erduran, \& P. Childs (Eds.), Electronic Proceedings of the ESERA 2017 Conference. Research, Practice and Collaboration in Science Education, Part 4 (pp. 573-582). Dublin.

Gutiérrez-Santiuste, E., Gallego-Arrufat, M.-J., \& Simone, A. (2016). Barriers in computer-mediated communication: typology and evolution over time. Journal of E-Learning and Knowledge Society, 12(1), 107-119.

Hammond, M., Reynolds, L., \& Ingram, J. (2011). How and why do student teachers use ICT? Journal of Computer Assisted Learning, 27(3), 191-203. http://doi.org/10.1111/j.1365-2729.2010.00389.x

Hennessy, S., \& London, L. (2013). Learning from international experiences with Interactive Whiteboards: The role of professional development in integrating the technology. OECD Education Working Papers, (89), 33. 
Hu, L. (2006). Teachers' beliefs and attitudes towards information communication and technology (ICT) and related pedagogy for English for Business Purposes (EBP) Education in Chinese Higher Education. King's College London, University of London.

Jaillet, A. (2004). What is happening with portable computers in schools? Journal of Science Education and Technology, 13(1), 115-128. http://doi.org/10.1023/B:JOST.0000019644.31745.9e

López, V., \& Pintó, R. (2011). Science teachers' perceptions of an educational challenge: A one-to-one project. In Proceedings of ESERA 2011 Conference. Lyon, France.

Mama, M., \& Hennessy, S. (2013). Developing a typology of teacher beliefs and practices concerning classroom use of ICT. Computers and Education, 68, 380-387. http://doi.org/10.1016/j.compedu.2013.05.022

Mouza, C., \& Barrett-Greenly, T. (2015). Bridging the app gap: An examination of a professional development initiative on mobile learning in urban schools. Computers and Education, 88, 1-14. http://doi.org/10.1016/j.compedu.2015.04.009

Murcia, K. (2014). Interactive and multimodal pedagogy: A case study of how teachers and students use interactive whiteboard technology in primary science. Australian Journal of Education, 58(1), 74-88. http://doi.org/10.1177/0004944113517834

Padrós Rodríguez, J. (2011). El Projecte EduCAT1x1. Què en pensen els implicats.

Pajares, F. M. (1992). Teachers' beliefs and educational research: Cleaning up a messy construct. Review of Educational Research, 62(3), 307-332. http://doi.org/10.3102/00346543062003307

Pedró, F. (2011). Tecnología y escuela: lo que funciona y por qué. Fundación Santillana.

Prestridge, S. (2012). The beliefs behind the teacher that influences their ICT practices. Computers \& Education, 58(1), 449-458. http://doi.org/10.1016/j.compedu.2011.08.028

Rogers, E. M. (2003). Diffusion of innovations (5th ed.). New York: Free Press. Retrieved from http://books.google.es/books?id=9U1K5LjUOwEC\&printsec=frontcover\&dq=Diffusion+of+innovations\&hl =ca\&ei=F5nfTu_kNcuM4gSzo5TeBg\&sa=X\&oi=book_result\&ct=result\&resnum=2\&ved=0CDIQ6AEwAQ $\# \mathrm{v}=$ onepage $\& \mathrm{q}=$ Diffusion of innovations $\& \mathrm{f}=$ false

Sheffield, C. C. (2015). Struggling to move beyond projection: A case study of instructional use of an Interactive White board in elementary Social Studies. Contemporary Issues in Technology and Teacher Education, 15(4), 541-567.

Sherin, M. G., Jacobs, V. R., \& Philipp, R. A. (Eds.). (2011). Mathematics teacher noticing: Seeing through teachers' eyes. New York: Routledge.

Tondeur, J., van Braak, J., Ertmer, P. A., \& Ottenbreit-Leftwich, A. (2017). Understanding the relationship between teachers' pedagogical beliefs and technology use in education: A systematic review of qualitative evidence. Educational Technology Research and Development, 65(3), 555-575.

http://doi.org/10.1007/s11423-016-9481-2 
Appendix 1: complete results of Mann-Whitney $U$ test about the possible impact of the training on teachers' use of the IWB

\begin{tabular}{|c|c|c|c|c|}
\hline & $\begin{array}{l}\text { Training based } \\
\text { on technical } \\
\text { characteristics }\end{array}$ & $\begin{array}{l}\text { General uses and } \\
\text { affordances }\end{array}$ & $\begin{array}{l}\text { Materials and } \\
\text { examples } \\
\text { designed by a } \\
\text { commercial } \\
\text { publisher }\end{array}$ & $\begin{array}{l}\text { Real examples } \\
\text { from other } \\
\text { teachers }\end{array}$ \\
\hline $\begin{array}{l}\text { 1. Show videos to students or } \\
\text { other dynamic information }\end{array}$ & $\begin{array}{c}\mathrm{X}_{\mathrm{no}}=25.72, \\
\mathrm{X}_{\mathrm{yes}}=28.94, \\
\mathrm{U}=384.500, \mathrm{r}=.496\end{array}$ & $\begin{array}{c}\mathrm{X}_{\mathrm{no}}=30.29 \\
\mathrm{X} \text { yes }=27.36 \\
\mathrm{U}=230.500 \\
\mathrm{r}=.573)\end{array}$ & $\begin{array}{c}\mathrm{X}_{\mathrm{no}}=28.37 \\
\mathrm{X}_{\mathrm{yes}}=27.18 \\
\mathrm{U}=309.000 \\
\mathrm{r}=.798)\end{array}$ & $\begin{array}{c}\mathrm{x}_{\mathrm{no}}=27.31 \\
\mathrm{x}_{\mathrm{yes}}=29.20 \\
\mathrm{U}=374.000 \\
\mathrm{r}=0,673)\end{array}$ \\
\hline $\begin{array}{l}\text { 2. Project slides or other files } \\
\text { supporting teachers' } \\
\text { explanations (except for } \\
\text { Digital Textbooks) }\end{array}$ & $\begin{array}{c}\mathrm{x}_{\mathrm{no}}=31.16 \\
\mathrm{x}_{\mathrm{yes}}=26.28 \\
\mathrm{U}=216.500 \\
\mathrm{r}=.346)\end{array}$ & $\begin{array}{c}\mathrm{x}_{\mathrm{no}}=24.08 \\
\mathrm{x}_{\mathrm{yes}}=29.08 \\
\mathrm{U}=315.000 \\
\mathrm{r}=.335)\end{array}$ & $\begin{array}{c}\mathrm{x}_{\mathrm{no}}=26.18 \\
\mathrm{x}_{\mathrm{yes}}=32.06 \\
\mathrm{U}=392.000 \\
\mathrm{r}=.206)\end{array}$ & $\begin{array}{c}\mathrm{x}_{\mathrm{no}}=28.56 \\
\mathrm{x}_{\mathrm{yes}}=27.02 \\
\mathrm{U}=330.500 \\
\mathrm{r}=0,731)\end{array}$ \\
\hline $\begin{array}{l}\text { 3. Teachers' showing Digital } \\
\text { textbooks }\end{array}$ & $\begin{array}{c}\mathrm{x}_{\mathrm{no}}=25.55 \\
\mathrm{x}_{\mathrm{yes}}=29.00 \\
\mathrm{U}=351.000 \\
\mathrm{r}=.462)\end{array}$ & $\begin{array}{c}\mathrm{x}_{\mathrm{no}}=26.00 \\
\mathrm{x}_{\mathrm{yes}}=28.56 \\
\mathrm{U}=282.000 \\
\mathrm{r}=.619)\end{array}$ & $\begin{array}{c}\mathrm{x}_{\mathrm{no}}=29.34 \\
\mathrm{x}_{\mathrm{yes}}=25.00 \\
\mathrm{U}=425.000 \\
\mathrm{r}=.344)\end{array}$ & $\begin{array}{c}\mathrm{x}_{\mathrm{no}}=27.14 \\
\mathrm{x}_{\mathrm{yes}}=29.50 \\
\mathrm{U}=380.000 \\
\mathrm{r}=, 593)\end{array}$ \\
\hline $\begin{array}{l}\text { 4. Teachers' searching and } \\
\text { showing of information on } \\
\text { the Internet }\end{array}$ & $\begin{array}{c}\mathrm{x}_{\mathrm{no}}=26.66 \\
\mathrm{X} \text { yes }=28.55 \\
\mathrm{U}=333.500 \\
\mathrm{r}=.687)\end{array}$ & $\begin{array}{c}\mathrm{X} \text { no }=31.79 \\
\mathrm{Xyes}=26.94 \\
\mathrm{U}=212.500 \\
\mathrm{r}=.349)\end{array}$ & $\begin{array}{c}\mathrm{X} \text { no }=30.04 \\
\mathrm{Xyes}_{\mathrm{yes}}=23.44 \\
\mathrm{U}=245.500 \\
\mathrm{r}=.154)\end{array}$ & $\begin{array}{c}\text { Xno }=30.86 \\
\text { Xyes }=23.00 \\
U=250.000 \\
r=, 077)\end{array}$ \\
\hline $\begin{array}{l}\text { 5. Comparison of students' } \\
\text { experimental predictions or } \\
\text { students' productions on the } \\
\text { IWB carried out by the } \\
\text { teacher }\end{array}$ & $\begin{array}{c}\mathrm{x}_{\mathrm{no}}=27.28 \\
\mathrm{x}_{\mathrm{yes}}=28.29 \\
\mathrm{U}=323.500 \\
\mathrm{r}=.790)\end{array}$ & $\begin{array}{c}\mathrm{X}_{\mathrm{no}}=27.29 \\
\mathrm{x}_{\mathrm{yes}}=28.20 \\
\mathrm{U}=266.500 \\
\mathrm{r}=.829)\end{array}$ & $\begin{array}{c}\mathrm{x}_{\mathrm{no}}=28.04 \\
\mathrm{X}_{\mathrm{yes}}=27.91 \\
\mathrm{U}=321.500 \\
\mathrm{r}=.973)\end{array}$ & $\begin{array}{c}\mathrm{x}_{\mathrm{no}}=28.34 \\
\mathrm{x}_{\mathrm{yes}}=27.40 \\
\mathrm{U}=338.000 \\
\mathrm{r}=, 796)\end{array}$ \\
\hline $\begin{array}{l}\text { 6. Making annotations on the } \\
\text { IWB to support teachers' } \\
\text { explanations }\end{array}$ & $\begin{array}{c}\mathrm{X}_{\mathrm{no}}=25.97 \\
\mathrm{X}_{\mathrm{yes}}=28.83 \\
\mathrm{U}=344.500 \\
\mathrm{r}=.523)\end{array}$ & $\begin{array}{c}\mathrm{x}_{\mathrm{no}}=21.33 \\
\mathrm{x}_{\mathrm{yes}}=29.86 \\
\mathrm{U}=338.000 \\
\mathrm{r}=.084)\end{array}$ & $\begin{array}{c}\mathrm{x}_{\mathrm{no}}=26.80 \\
\mathrm{x}_{\mathrm{yes}}=30.68 \\
\mathrm{U}=368.500 \\
\mathrm{r}=.380)\end{array}$ & $\begin{array}{c}\mathrm{x}_{\mathrm{no}}=25.91 \\
\mathrm{X}_{\mathrm{yes}}=31.65 \\
\mathrm{U}=423.000 \\
\mathrm{r}=, 176)\end{array}$ \\
\hline $\begin{array}{l}\text { 7. Teachers' interacting with } \\
\text { the IWB (other types of } \\
\text { interaction different from } \\
\text { writing, such as drag \& drop } \\
\text { or scroll down) }\end{array}$ & $\begin{array}{c}\mathrm{X}_{\mathrm{no}}=26.69 \\
\mathrm{X}_{\mathrm{yes}}=28.54 \\
\mathrm{U}=333.000 \\
\mathrm{r}=.670)\end{array}$ & $\begin{array}{c}\mathrm{Xno}=25.17 \\
\mathrm{Xyes}=28.79 \\
\mathrm{U}=292.000 \\
\mathrm{r}=.449)\end{array}$ & $\begin{array}{c}\mathrm{X}_{\mathrm{no}}=24.64 \\
\mathrm{Xyes}=35.50 \\
\mathrm{U}=450.500 \\
\mathrm{r}=.011)\end{array}$ & $\begin{array}{c}\mathrm{Xno}_{\mathrm{no}}=23.56 \\
\mathrm{Xyes}=35.82 \\
\mathrm{U}=506.500 \\
\mathrm{r}=, 003)\end{array}$ \\
\hline $\begin{array}{l}\text { 8. Students' writing on the } \\
\text { IWB }\end{array}$ & $\begin{array}{c}\mathrm{x}_{\mathrm{no}}=23.62 \\
\mathrm{x}_{\mathrm{yes}}=29.79 \\
\mathrm{U}=382.000 \\
\mathrm{r}=.137)\end{array}$ & $\begin{array}{c}\mathrm{X}_{\mathrm{no}}=22.75 \\
\mathrm{X}_{\mathrm{yes}}=29.47 \\
\mathrm{U}=321.000 \\
\mathrm{r}=.142)\end{array}$ & $\begin{array}{c}\mathrm{x}_{\mathrm{no}}=28.59 \\
\mathrm{x}_{\mathrm{yes}}=26.68 \\
\mathrm{U}=300.500 \\
\mathrm{r}=.639)\end{array}$ & $\begin{array}{c}\mathrm{x}_{\mathrm{no}}=25.93 \\
\mathrm{x}_{\mathrm{yes}}=31.62 \\
\mathrm{U}=422.500 \\
\mathrm{r}=, 146)\end{array}$ \\
\hline $\begin{array}{l}\text { 9. Students' interacting with } \\
\text { the IWB (other types of } \\
\text { interaction different from } \\
\text { writing, such as drag \& drop } \\
\text { or scroll down) }\end{array}$ & $\begin{array}{c}\mathrm{X}_{\mathrm{no}}=26.09 \\
\mathrm{Xyes}=28.78 \\
\mathrm{U}=342.500 \\
\mathrm{r}=.329)\end{array}$ & $\begin{array}{c}\mathrm{Xno}=28.67 \\
\mathrm{Xyes}=27.81 \\
\mathrm{U}=250.000 \\
\mathrm{r}=.778)\end{array}$ & $\begin{array}{c}\mathrm{X}_{\mathrm{no}}=28.07 \\
\mathrm{X}_{\text {yes }}=27.85 \\
\mathrm{U}=473.500 \\
\mathrm{r}=.937)\end{array}$ & $\begin{array}{c}\text { Xno }=26.76 \\
\text { Xyes }=30.18 \\
U=393.500 \\
r=, 189)\end{array}$ \\
\hline 10. Realization of polls & $\begin{array}{c}\mathrm{X}_{\mathrm{no}}=30.44, \\
\mathrm{X}_{\mathrm{yes}}=27.00, \\
\mathrm{U}=273.000, \mathrm{r}=- \\
.026)\end{array}$ & $\begin{array}{c}\mathrm{x}_{\mathrm{no}}=29.25 \\
\mathrm{x} \text { yes }=27.65, \\
\mathrm{U}=243.000, \mathrm{r}=- \\
.346)\end{array}$ & $\begin{array}{c}\mathrm{x}_{\mathrm{no}}=27.00 \\
\mathrm{x}_{\mathrm{yes}}=30.24 \\
\mathrm{U}=361.000 \\
\mathrm{r}=.033)\end{array}$ & $\begin{array}{c}\mathrm{x}_{\mathrm{no}}=27.80 \\
\mathrm{X}_{\mathrm{yes}}=28.35 \\
\mathrm{U}=357.000 \\
\mathrm{r}=, 706)\end{array}$ \\
\hline $\begin{array}{l}\text { 11. Teachers' realization of an } \\
\text { animated final summary } \\
\text { through the software of the } \\
\text { IWB }\end{array}$ & $\begin{array}{c}\mathrm{X}_{\mathrm{no}}=26.50 \\
\mathrm{X}_{\text {yes }}=28.62 \\
\mathrm{U}=336.000 \\
\mathrm{r}=.258)\end{array}$ & $\begin{array}{c}\mathrm{Xno}_{\mathrm{no}}=26.50 \\
\mathrm{X}_{\mathrm{yes}}=28.42 \\
\mathrm{U}=276.000 \\
\mathrm{r}=.351)\end{array}$ & $\begin{array}{c}\mathrm{X}_{\mathrm{no}}=28.67 \\
\mathrm{X}_{\text {yes }}=26.50 \\
\mathrm{U}=297.500 \\
\mathrm{r}=.238)\end{array}$ & $\begin{array}{c}\mathrm{Xno}_{\mathrm{no}}=28.04 \\
\mathrm{Xyes}=27.92 \\
\mathrm{U}=348.500 \\
\mathrm{r}=, 947)\end{array}$ \\
\hline 12. Other uses & $\begin{array}{c}\mathrm{x}_{\mathrm{no}}=28.00 \\
\mathrm{x}_{\mathrm{yes}}=28.00 \\
\mathrm{U}=312.000 \\
\mathrm{r}=1.000)\end{array}$ & $\begin{array}{c}\mathrm{x}_{\mathrm{no}}=28.00 \\
\mathrm{x}_{\mathrm{yes}}=28.00 \\
\mathrm{U}=258.000 \\
\mathrm{r}=1.000)\end{array}$ & $\begin{array}{c}\mathrm{x}_{\mathrm{no}}=28.00 \\
\mathrm{x}_{\mathrm{yes}}=28.00 \\
\mathrm{U}=323.000 \\
\mathrm{r}=1.000)\end{array}$ & $\begin{array}{c}\mathrm{x}_{\mathrm{no}}=28.00 \\
\mathrm{x}_{\mathrm{yes}}=28.00 \\
\mathrm{U}=350.000 \\
\mathrm{r}=1.000)\end{array}$ \\
\hline
\end{tabular}

